\title{
Trichosporon beigelii
}

National Cancer Institute

\section{Source}

National Cancer Institute. Trichosporon beigelii. NCI Thesaurus. Code C127761.

A species of urease-positive, non-encapsulated yeasts in the phylum Basidiomycota

characterized by the development of hyaline, septate hyphae that fragment into oval or rectangular arthroconidia. 